\title{
Cliff Tomb Burial and Decorated Stone Sarcophagi from Sichuan from the Eastern Han Dynasty
}

\author{
Hajni Pejsue ELIAS*
}

\begin{abstract}
Cliff tombs and decorated stone sarcophagi from the Eastern Han period have been found in especially large numbers in Sichuan. The sudden rise of cliff tomb burial in the southwest and its decline by the 3rd century CE suggests that it was a trend that answered a particular call in a specific period. Their geographical concentration and use in a period of general social and political stability and economic prosperity in the region point to a distinctive new development in burial custom. Cliff tomb burial represented a fundamental shift in artistic and communicative objectives and a modification in cemetery layout. After examining cliff tombs found in Hejiang county, Sichuan, and especially the iconography and meaning of images carved on stone sarcophagi found therein, the paper suggests a number of possible reasons for the rise of cliff tomb burial, including a wish to eschew the ostentation associated with funereal practice at the time.
\end{abstract}

Keywords: Eastern Han, cliff tombs, stone sarcophagi, tomb decoration, southwest China

\section{Skalne grobnice in okrašeni kamniti sarkofagi iz province Sichuan iz obdobja dinastije Vzhodni Han}

\section{Izvleček}

V provinci Sichuan je bilo odkritih veliko skalnih grobnic in okrašenih kamnitih sarkofagov iz dinastije Vzhodni Han. Nenadni pojav skalnih grobnic na jugozahodu in upad teh v 3. stoletju kažeta, da je šlo za težnjo, ki je zadostila posebnim zahtevam v tem specifičnem obdobju. Njihova geografska zgoščenost in uporaba $v$ obdobju splošne družbene in politične stabilnosti ter gospodarske blaginje $\mathrm{v}$ regiji kažeta na povsem nov razvoj $\mathrm{v}$ pogrebnih običajih. Skalne grobnice tako predstavljajo temeljno spremembo v umetniških in komunikacijskih težnjah ter spremembo $\mathrm{v}$ načrtu pokopališč. Po proučitvi skalnih grobnic, najdenih v okrožju Hejiang v provinci Sichuan, in zlasti ikonografije in pomena podob, izklesanih na kamnitih sarkofagih znotraj grobnic, prispevek predstavi več možnih razlogov za porast skalnih pokopov, med katerimi izpostavi predvsem težnjo po izogibanju pompoznemu razkazovanju, ki je bilo povezano s takratno pogrebno prakso.

Ključne besede: Vzhodni Han, skalne grobnice, kamniti sarkofagi, dekoracija grobnic, jugozahodna Kitajska

Hajni Pejsue ELIAS, PhD,

Faculty of Asian and Middle Eastern Studies, University of Cambridge.

Email address: hpe20[at]cam.ac.uk

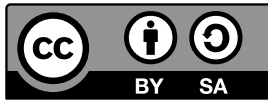




\section{Introduction}

To date, tens of thousands of cliff tombs from the Eastern Han period (25-220 $\mathrm{CE})$ have been discovered, primarily located in the Sichuan Basin, along the Yangtze river and its larger tributaries, the Min 岷, Tuo 沱 and Fu Rivers 涪江. The sudden emergence of cliff tombs and their proliferation during the first and second centuries CE confirm their importance in the region's funerary customs. Their concentration in geography and time points to a distinctive new development in burial practice. The popularity of cliff tomb burial in the southwest appears to have coincided with a period of relative social and political stability and great economic prosperity. From textual sources it is evident that there was a wish, on the part of some, for moderation and frugality in a society that was becoming increasingly aware of its unnecessary extravagance. ${ }^{1}$ This paper argues that this wish for more frugal ways of life is reflected in the region's cliff tomb burial practice in which not one, but several family members were buried together in a single tomb. Cliff tomb decoration was also sparser than that seen in contemporaneous chamber tombs, which in many instances display pictorial brick tiles and stone reliefs throughout the interior of the tomb space. Furthermore, cliff tombs represented a change in the layout of cemeteries and in the location where funerary rites and ancestral sacrifices were conducted. Therefore, cliff tomb burial was not a more ordinary or economical version of entombment for the poorer section of the population, as suggested by some scholars, but a distinct type of burial that became widely used by the inhabitants of the southwest, including those with considerable means (Luo 2002; Xuan 2015; Xie 2000). ${ }^{2}$ The sudden rise of cliff tomb burial in large numbers in the 1 st century $\mathrm{CE}$, and its decline by the 3rd century suggests that it was a trend that answered a particular call during a specific period. While burial practices changed in other regions of the Eastern Han Empire, this paper cannot examine all of these developments but focuses on the southwest where this phenomenon is found. Further study might show how other regions adjusted burial practices in response to their changing political and social circumstances.

1 The increasing visibility and excessive display of elaborate ritual procedures and practices of the Ruists led thinkers like Wang Chong 王充 to advocate frugality and criticise extravagance and conspicuous consumption, especially in relation to the increasingly complex and costly funerary displays of their time. Wang questioned the necessity for lavish burials, along with the belief in the existence of ghosts and shen 神, which drove people to indecent behaviours. He dedicates whole chapters in the Lunheng 論衡 to challenge what he termed as false and nonsensical notions of his day. See Lunheng jiaoshi 論衡校釋 (Critical Explanation of the Balanced Discussions) (Wang 1990, 62: “Lun si” 論死; 63: “Si wei” 死偽 and 64: “Ji yao” 紀妖).

2 Xie (2000,18-25) also proposes that inscriptions found in cliff tombs are generally short in content and crude in style, confirming the ordinary nature of cliff tomb burial. 


\section{Overview of the Southwest's Early Burial Practices}

Archaeological discoveries have shed light on early burial customs in the southwest. Stone coffins placed in stone-lined pits, belonging to the "cist tomb culture" of the Neolithic period, have been unearthed in the upper Min River valley which scholars have identified as affiliated with the Shu 蜀 peoples and their burial culture (Orioli 1994; Xu 1995). Another type of burial practice came to light with the discovery of graves containing wooden, boat-shape coffins (Mengoni 2004). Dated to the fifth to the fourth centuries BCE, these coffins have been ascribed by scholars as belonging to the $\mathrm{Ba} 巴$ peoples of the southwest (Sage 1992). ${ }^{3}$ By the third and second centuries BCE, wooden encasements placed in simple rectangular pits became the most widespread form of burial in the region, while boat coffins gradually disappeared (Mengoni 2004, 54). From the Western Han (206 BCE-9 CE) to the beginning of the Eastern Han period, traditional vertical shaft pits were superseded by brick and stone chamber tombs, and from the second half of the Eastern Han period there was a substantial decrease in the number of chamber tombs, with cliff tombs established as the predominant tomb type in Sichuan (Sichuan sheng wenwu kaogu yanjiuyuan 2014). Cheng Te-k'un (1908-2001), an archaeologist and curator of the West China University Museum at Chengdu in the 1930s, suggested that cliff tombs evolved from brick chamber tombs and represented a new burial custom which gradually gained popularity in the Eastern Han and came to dominate the region's burial practice (Cheng 1957). Wu Hung supports Cheng's findings and draws our attention to cliff tombs as representative of the zenith of Sichuan tomb art and architecture (Wu 1987, 94). In summary, scholars are generally in agreement that cliff tombs are distinct to the southwest, and that this type of burial practice became standard and the prevalent form of burial in the region by the Eastern Han dynasty.

\section{Distribution of CliffTombs and Decorated Stone Sarcophagi in the Southwest}

The majority of decorated stone sarcophagi from the Eastern Han period are found in Sichuan, with a small number from the area occupied by present-day Guizhou 貴州 and Chongqing 重慶 (Gao 2011). This finding suggests that by the first and second centuries $\mathrm{CE}$, decorated stone sarcophagi were primarily

3 The historical references to the region of present day Sichuan province and Chongqing Municipality for the period between the fifth and second centuries BCE mention two ancient states: Shu and Ba. Archaeological material dated from the Han period, especially if excavated from funerary contexts, has thus generally been grouped and interpreted under the labels Ba culture, Shu culture or Ba-Shu culture. These terms have strong cultural and ethnic connotations (see Mengoni 2004, 52). 
employed in the southwest where cliff tombs became the preferred means of burial, as mentioned above (Erickson 2003, 405). The main locations of cliff tombs where stone sarcophagi have been found in the southwest are along the hill-sides of the upper Yangtze river in the Chuanxi plain 川西平原 near Leshan 樂山 and Pengshan 彭山 counties; along the Yangtze and its larger tributaries, the Min and Tuo rivers located in the Chengdu plain; and along the Fu and Yangtze river valleys near Luzhou city 蘆州 and Hejiang 合江 county (Luo 2000, 47) (Map 1).

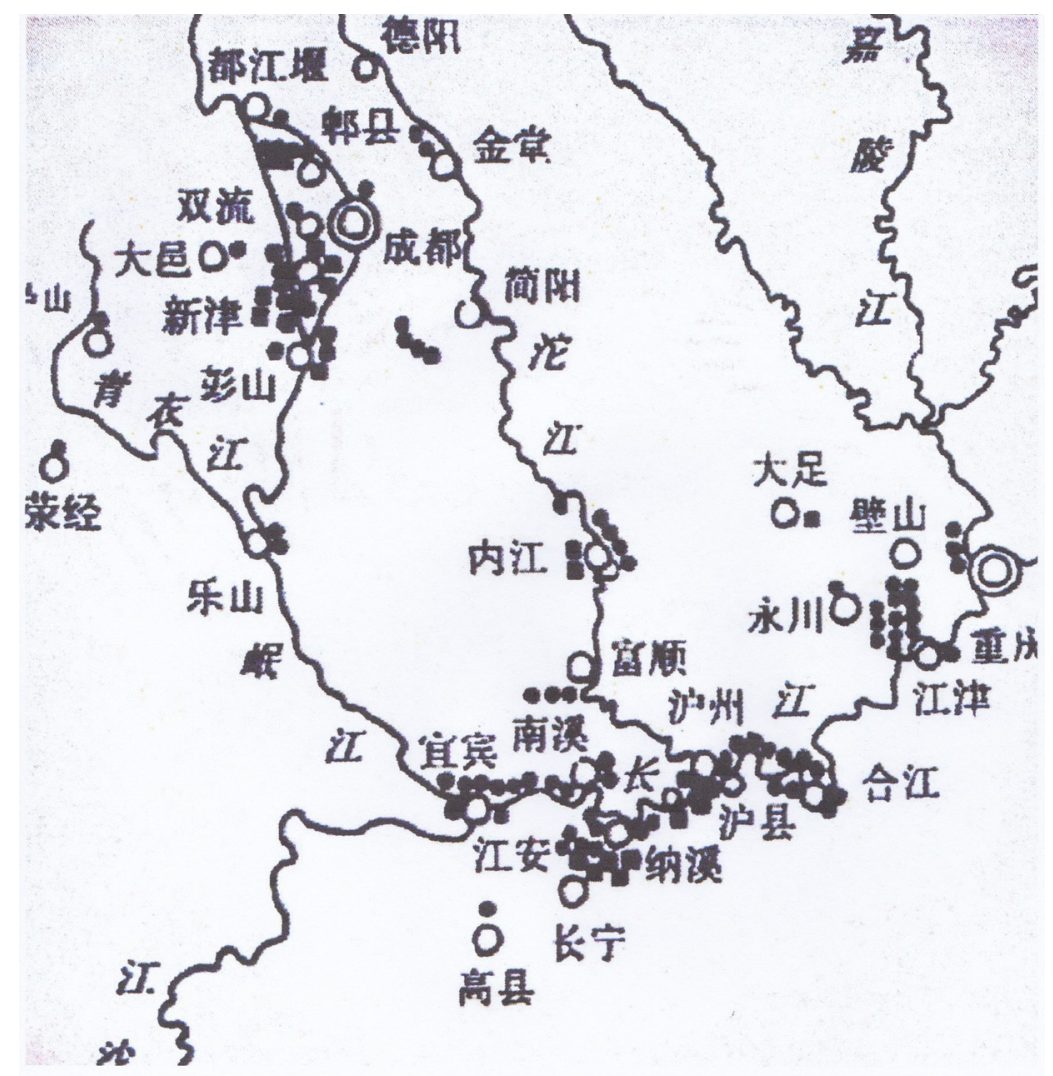

Map 1: Distribution of Eastern Han Dynasty cliff tombs and stone sarcophagi excavated in Sichuan (Luo 2000, 47).

Regarding the size and layout of the tombs, they vary in scale, with some containing a single shallow burial chamber of a few metres in length, while others, extending over tens of meters into the mountain side, are constructed with multiple chambers to accommodate numerous coffins. They are usually laid out in groups, resembling a small cemetery, with tombs positioned next to each other horizontally, and forming several layers vertically along the upper reaches of the hills and mountain sides (Wu 2000, 79). 


\section{Cliff'Tombs at Hejiang County}

In order to understand the general layout of cliff tombs and how they may have been used, let us take a closer look at examples discovered at Hejiang county. Situated along the upper Yangtze river, Hejiang county has one of the largest number of cliff tombs as well as decorated stone sarcophagi in Sichuan discovered to date. Over 1,250 cliff tomb cemetery complexes have been found in the county, predominantly along the banks of the Yangtze, the Chishui 赤水 and the Xishui 習水 rivers. There are more than 50 cliff tomb complexes which hold ten or more tombs (Figs. 1a, 1b). ${ }^{4}$
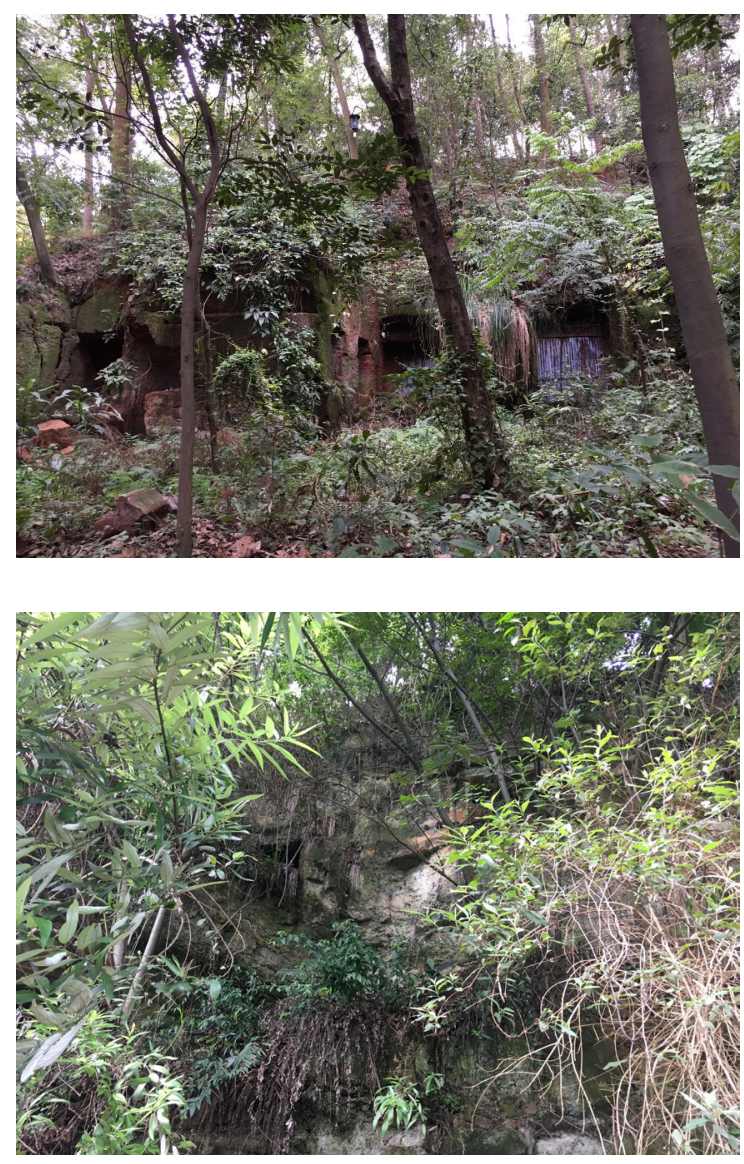

Figures 1a, 1b: Cliff tombs at Hejiang county, Sichuan (Photos by Author).

4 This information was obtained from a personal interview with the Hejiang County Han Dynasty Pictorial Stone Sarcophagi Museum (Hejiang xian Handai huaxiang shiguan bowuguan 合江縣漢 代畫像石棺博物館) director, Zhang Caixiu 張采秀, during field trip conducted at the museum in May, 2016. 
For entombing the dead, coffins made in wood, earthenware and stone were placed in them, although today we only have a small number of earthenware coffins and almost no wooden coffins are left intact. Due to the durability of their material, stone sarcophagi have survived in the largest numbers and are therefore, alongside mingqi 明器 objects, the primary material culture for the study of cliff tomb burial in the region. On average, stone sarcophagi weigh around 1-1.5 tons, and are approximately 2.25 metres in length, 0.66 metres in height and 0.62 metres in width. The Hejiang County Han Dynasty Pictorial Stone Sarcophagi Museum alone holds over 60 decorated stone sarcophagi in its collection (Gao 2002, 6).

The proliferation of cliff tomb burials and the use of stone sarcophagi in Hejiang county appear to be closely connected to its geography, economic wealth and political importance, which developed as early as the Western Han period. Hejiang county, known in ancient times as Fu county 苻縣, was established in $115 \mathrm{BCE}$ (Li 1989, 33.2788; Ban 1962, 28A.1599). It first became prominent when the Han envoy, Tang Meng 唐蒙, was appointed to lead a military force of 1,000 soldiers and over 10,000 porters out of the county to visit the Marquis of Yelang 夜郎, Duotong 多同 (Sima 1959, 116.2994). According to Sima Qian's account, Tang Meng presented Duotong with generous gifts and, pronouncing the might and virtue of the Han Dynasty, urged him to permit officials to be sent to the area. Everyone in Yelang was keen to obtain silk from the Han, and Duotong, considering that the road between his territory and the Han Empire was too steep and perilous to be kept open for long, agreed to listen to Tang's demands. Tang then returned to the capital to report on his mission. As a result, a commandery was established in the area and conscripts from $\mathrm{Ba}$ and Shu were sent out to work on its roads, extending them through Po 梀束 in the direction of the Zangke 靕柯 River (Sima 1959, 116.2994; Wade 2009, 188). Thus, Fu county's position as a military and economic centre of strategic importance to the Han government is evident from early records.

One of the most important cliff tomb complexes in Hejiang is located near the small town of Fubaozhen 福寶鎮, known as the Gaocun cliff tomb (Gaocun yamu 高村崖墓) complex. This complex or cemetery contains 205 independent tombs carved into the side of a hill covering an area of approximately 850 metres in length. The majority of the tombs are small in scale, primarily containing a single chamber with a dome-shaped ceiling. Those that are accessible from the road without climbing are built at the end of a narrow tomb passage carved into the face of the cliff. ${ }^{5}$ Each passage, called the tomb road (mudao 墓道), leads

5 Information was obtained from the archives of the Hejiang County Han Dynasty Pictorial Stone Sarcophagi Museum (Hejiang xian Handai huaxiang shiguan bowuguan 合江縣漢代畫像石棺博 物館) and from personal experience during field trip conducted at Gaocun in May, 2016. 
to the primary entrance of the tomb known as the tomb gate (mumen 墓門). Through the tomb gate one enters the main chamber (mushi 墓室), which may contain a single chamber or have further niche openings in the side and back walls (bikan 壁龕). The main chamber, which is usually the largest space in the tomb, contains the area known as the front room (qianshi 前室), or sacrificial chamber (xiangtang 享堂) (Wen 1955), where the ceiling is built slightly higher to allow a more comfortable standing space for people to conduct rituals and to offer sacrifices (Huo 2008, 297). Sacrificial chambers are known from chamber tombs where an altar was set for conducting rituals and sacrifices to the dead in the front section of the tomb space. Some of the cliff tombs also contain a "kitchen" area with a stove and shelves carved as part of the tomb wall. The addition of such prima facie practical and utilitarian spaces substantiates the equivalence of the tombs with a home (Erickson 2003, 414-15) (Figs. 2a, 2b). The interiors of the tombs were generally left plain, but some have been found decorated with simple carved pictorial freezes above built-in architectural structures, such as beds, couches and cliff sarcophagi (Figs. 3a, 3b).
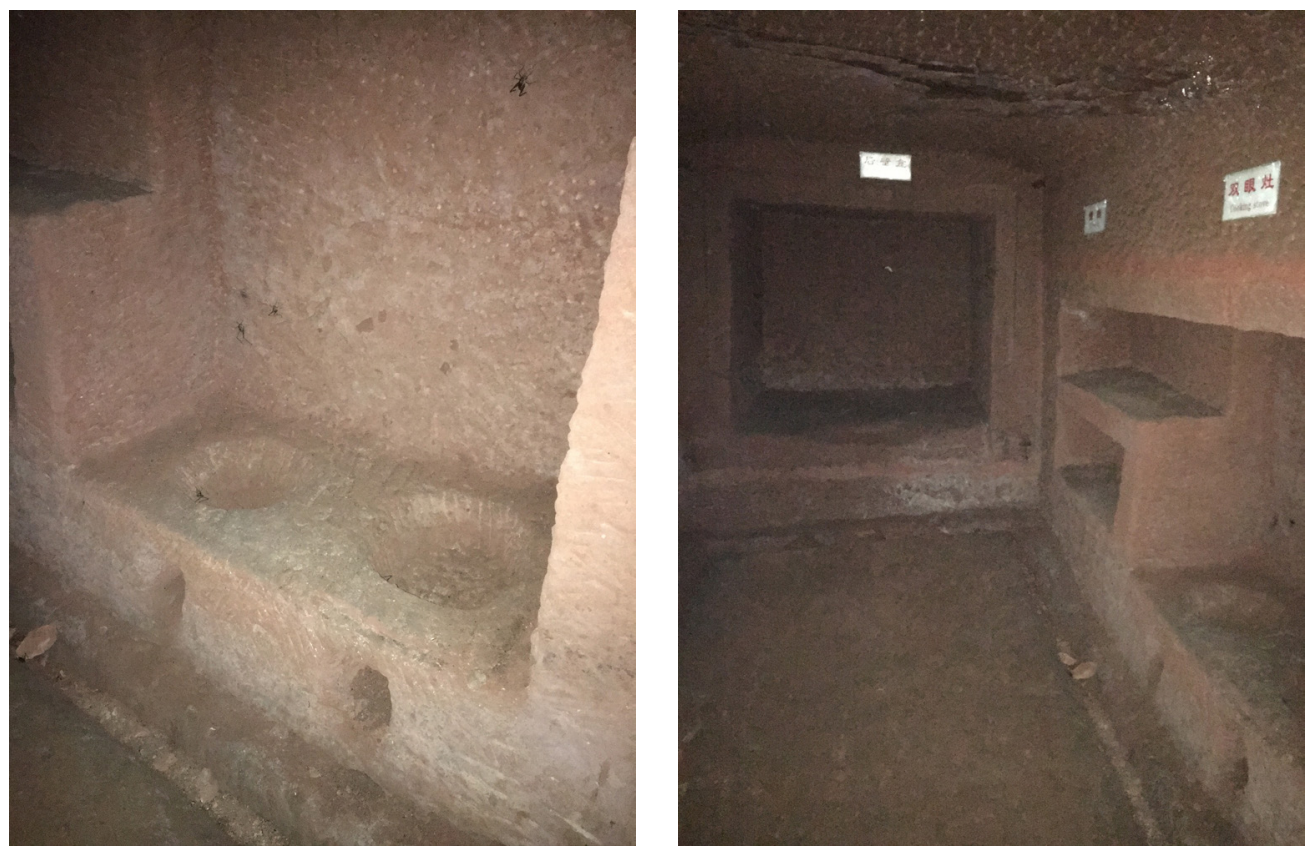

Figures 2a, 2b: Interior of a cliff tomb, Gaocun, Sichuan (Photos by Author). 

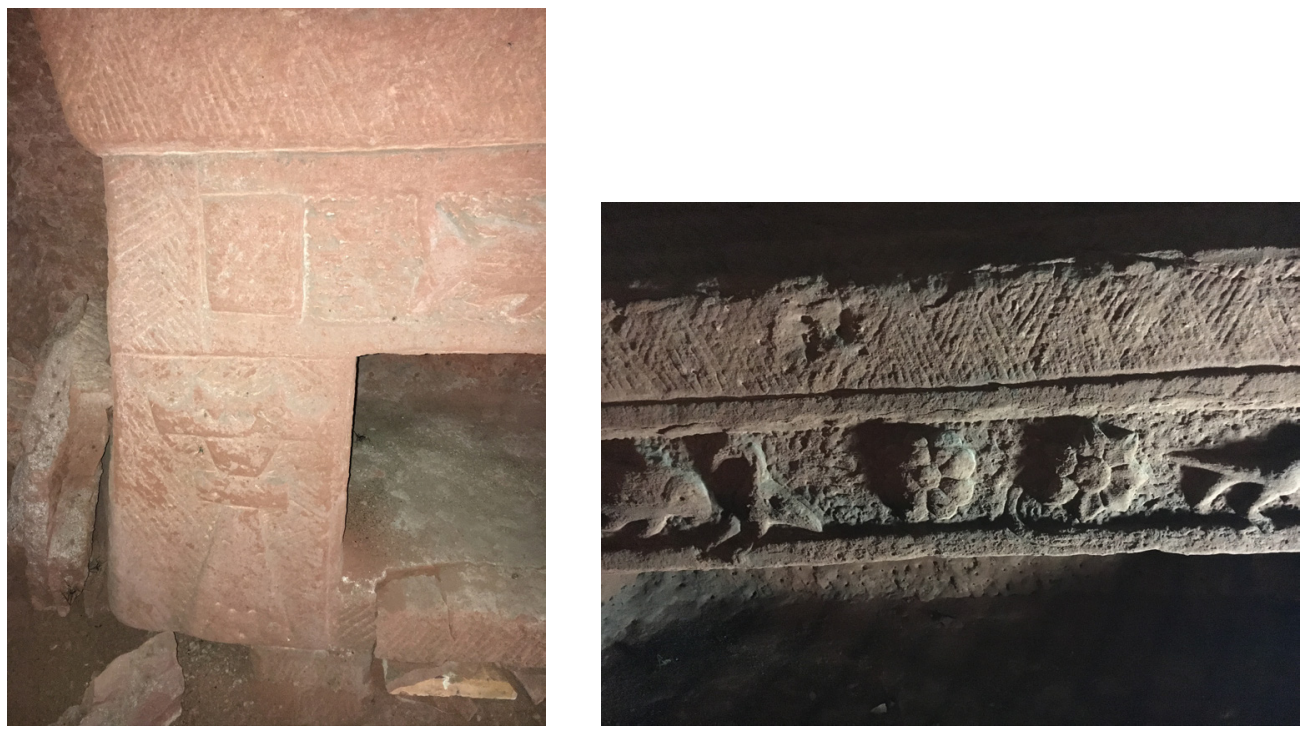

Figures 3a, 3b: Interior wall decoration in a cliff tomb, Gaocun, Sichuan (Photos by Author).

There are no traces of wall hangings or wall paintings apart from somewhat crudely painted architectural beams and structures, which suggest that hanging decoration, if it existed, may have perished or been plundered over time. Since, however, there are no markings or obvious means of fixing to be seen on the walls of the tombs, it is unlikely that hangings were an aspect of the tombs' interior decoration (Nylan and Loewe 2010, 88). ${ }^{6}$ It is worth noting that the walls of cliff tombs were carved in a particular manner whereby the stone was chiselled out with well-defined thick lines extending from top to bottom, left to right, often in a horizontal, vertical or diagonal lines, creating distinct patterns on the surface of the stone that left it rough to the touch. Cliff tomb walls are rarely smooth, and to paint any decoration on such an uneven surface would have been a challenge and aesthetically not very pleasing (Figs. 4a, 4b).

The decoration found in larger cliff tombs is simple and modest compared to that found in some of the region's chamber tombs, where fired pictorial brick tiles and larger blocks of stone relief carvings were placed on the smooth surface of the walls for decoration, and often not only in one area but throughout the tomb's interior space. ${ }^{7}$ Cliff tombs contained, as did chamber tombs, mingqi in the form

$6 \quad$ Nylan and Loewe 2010, 88, also mention that chamber tombs were often decorated with fabric, presumably made of silk, hanging on the walls of principal chambers.

7 See for example the chamber tomb unearthed at Yangzishan 揚子山, located in the suburb of Chengdu city, that was decorated with a series of pictorial brick tiles and stone reliefs throughout its interior. For a full excavation report on the Yangzishan tomb see Yu 1955. 
of pottery figurines of humans and domestic animals, pots and vessels of various shapes, architectural models of granaries, buildings and farm enclosures, a common practice in burial throughout the empire.
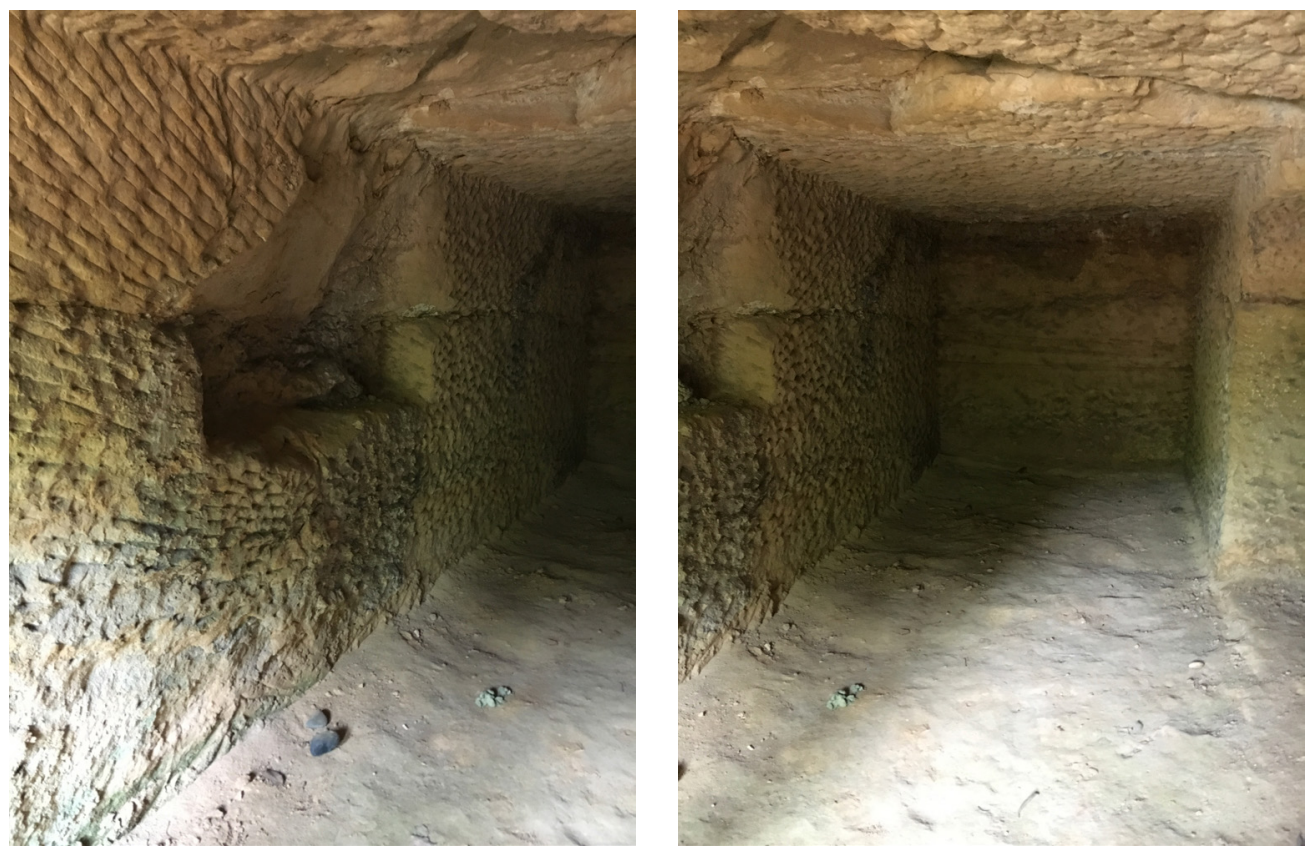

Figures 4a, 4b: Interior of a cliff tomb, Gaocun, Sichuan (Photos by Author).

The layout of cliff tomb complexes differs significantly from that of chamber burial cemeteries from the same period. Eastern Han cemeteries with a vertical shaft pit and chamber tombs were customarily demarcated by walls, moats, mounds or stone markers as a separate bordered space. They resembled large rectangular parks with the location often determined through divination (Barshier 2014, 292). Known as funerary parks (zangyuan 葬園), the tombs of several families were placed in areas separated by clearly marked moats. Liu Xixiang, in his report on a Han cemetery excavated at Xinxiang 新鄉 in Henan province, notes how the cemetery itself was divided into a number of "districts," each of which contained an independent family cemetery within the larger park (Liu 2007, 46-9). Burial sites within the cemetery were marked by a tumulus above each tomb. Leading to the tumuli were pathways called the spirit path (shendao 神道) that were marked by a pair of gate towers or que 閣. Visitors or family members of the deceased embarked on the spirit path that led them through the gate towers, after which they encountered a number of stone sculptures in 
the form of guardian animals. Following the path, they would come to a stele (or two stelae) erected in front of an ancestral shrine (zongmiao 宗廟), with the tumulus behind it (Wu 1995, 189-250). Cliff tomb burials showed a marked change in the layout of the Eastern Han cemetery. Compared to burial complexes that housed the spirit path, que, ancestral stele, shrine and the mound, cliff tomb cemeteries appear to have lacked much of these accompanying public monuments and spaces. Firstly, there is no marked boundary around the cemetery site, nor any spirit road lined up with stone sculptures leading to the tombs. The lack of que leading to the cliff tomb is mentioned in a commemorative stele erected for the “filial and incorrupt (xiaolian 孝廉)" official Liu Min 柳敏 ( $f$ l. $146 \mathrm{CE}$ ) which is worth examining in more detail. The eulogy section of the stele reads as follows:

山陵玄室, $[X]$ 斯邦兮. 先人修質, 尚約清兮. 汶飭不雕, 隩處藏兮. 季子 信舊, 帶樹松兮. 僑俗追歿, 激 $[\mathrm{X}]$ 揚兮. 亡而像存, 樂嘉靈兮. 宗子於 集, 㫮其鳴兮. 四祀 $[X]$ 嘗, 不廢荒兮. ${ }^{8}$

The mountain tomb is a dark room, ${ }^{9}[\mathrm{X}]$ this is [now his] country ah! [His] ancestors cultivated plainness and gave precedence to restraint and clarity ah! ${ }^{10}$ Patterns are orderly and [there is] no carving, [everything is] concealed in the cave ah! [His] youngest brother faithful to old tradition [buried him under a] belt of trees and pines ah! [He] rose above custom pursuing [it to the] end, and [thus] surges [X] [how] exalting ah! [Although] he has perished, yet his image remains, [we] rejoice in his auspicious spirit ah! His ancestors and sons have gathered here, keeyeh-keeyeh they cry ah! The four sacrificial [offerings] have been tasted, nothing has been omitted and neglected ah! (Gao 1990, 69)

Liu Min's final resting place is described as a dark room in a mountain surrounded by trees and pines, suggesting that we are looking at a cliff tomb burial. The interior of the tomb is concealed in a cave that bears no decoration. We are also told that his ancestors cultivated austerity and gave precedence to moderation. Liu was buried in a manner that conformed with his family's wish for a burial that was not only simple but also fulfilled the necessary requirements, with nothing omitted that would help his spirit remain auspicious. In an earlier section, the text

$8 \quad[\mathrm{X}]$ represents characters that are undecipherable due to damage to the stone.

9 Nylan and Vankeerberghen (2015, 404-5, 551) mention xuanshi 玄室 as a grave, a hidden and recessed room suitable for storing treasures or a dark meditation chamber.

10 I have translated $z h i$ 質 as "plainness" as I believe in this context its meaning gives priority to simplicity that is in sharp contrast with adornments and trappings. For a discussion on the different interpretations of $z h i$ and its usage with wen 紋, see Loewe (2011,275-86). 
on the stele describes Liu as a person who was honest, measured and frugal, and a man who encouraged his sons and grandsons to follow in this custom. His final resting place was a hall with no ornament and magnificence, and his grave had no ancestral stele marking its location (堂無文麗, 墓無碑誌). As mentioned earlier, the path leading to his tomb had no remains of a que (行無遺閲), which confirms the lack of monuments leading up to the tomb. Thus, Liu Min's stele, which was erected sometime after his death in commemoration of his official service, affirms intentional moderation and restraint from display and extravagance as a style of burial in the region, and celebrates a preference for frugality and moderation in accordance with the family's traditions.

Stelae positioned in front of shrines appear to have been omitted altogether, although sometimes replaced by inscriptions carved on the tomb walls or on the entrance gates. Compared to ancestral stele inscriptions, those found in cliff tombs are concise, with the majority containing only a few characters (Gao 1990, 18; Davis 2015, 177-80). Although the tomb interior included a special area for conducting funerary rites as found in chamber tombs, the nature of that space within the tomb is generally very limited in both area and height and not conducive to a sizeable gathering. It was almost physically impossible to accommodate more than a few people, let alone groups or crowds in cliff tombs, which suggests that ceremonies at such tomb sites must have been more intimate affairs (Fe 1965, 62.2067; Asselin 2010, 249). ${ }^{11}$ Where funerary rites were conducted for cliff tomb burials remains unanswered, although it is noteworthy that any substantial ceremony must have taken place significantly removed from the tomb site itself.

Cliff tombs also reflect a new development in grave construction. To keep the tomb dry, it was necessary to build drainage to allow water which would accumulate in the excavated cave to flow out. Tomb builders found a solution to the problem that was possible with cliff tombs but not with chamber tombs, whereby a drainage system was built into the tomb that comprised a horizontal stone base with several meters of pottery pipes that drew water from the interior of the tomb to the tomb passage outside. To this day we can see this kind of built-in drainage system with the original Han pipes clearly visible and intact, protruding at the entrance (Figs. 5a, 5b).

11 The Hou Hanshu 後漢書 (Book of the Later Han) (Fan 1965, 62.2067) records the biography of Chen Shi 陳定 (104-186 CE) who was buried in a chamber tomb and was mourned by thirty thousand people in attendance. Asselin (2010, 249) notes that funerals of officials, patrons and teachers in the late Eastern Han attracted hundreds, if not thousands of people, and participation in the funerary rites was at once an act of filial piety as well as a political one that demonstrated one's commitment to the policies or teachings of the departed. 

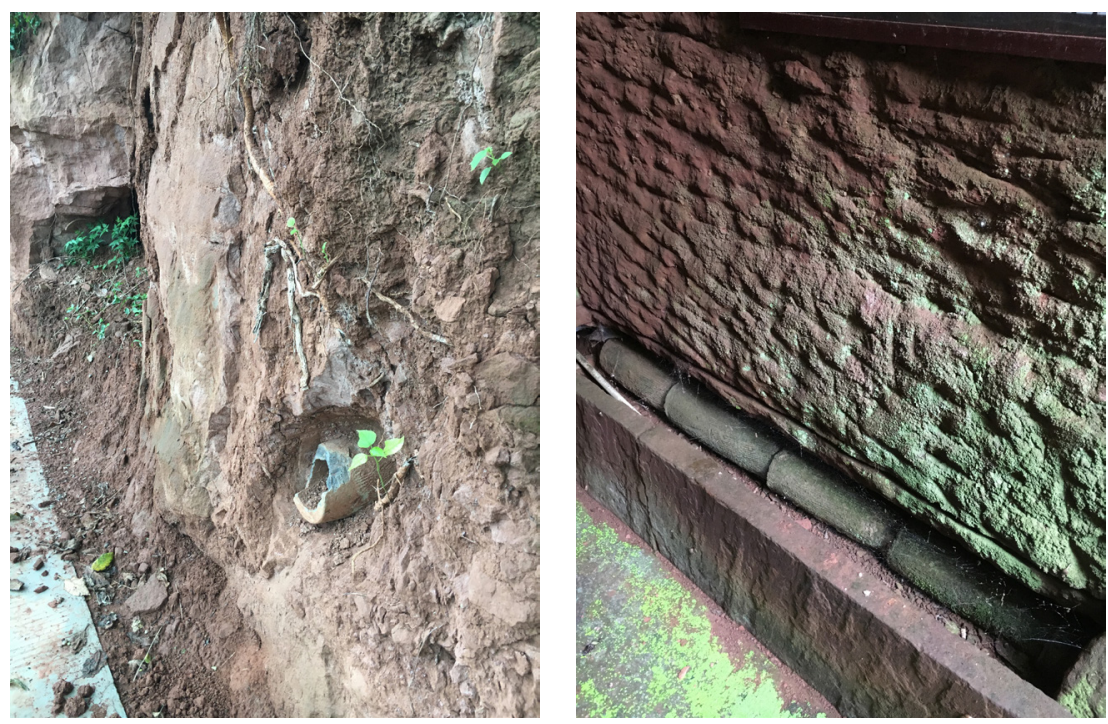

Figures 5a, 5b: Cliff tomb drainage pipes, Pengshan, Sichuan (Photos by Author).

\section{Cliff'Tomb Decoration}

As mentioned earlier, cliff tombs were generally left undecorated or with some minimal decoration placed at the entrance or tomb gate (Figs. 6a, 6b).
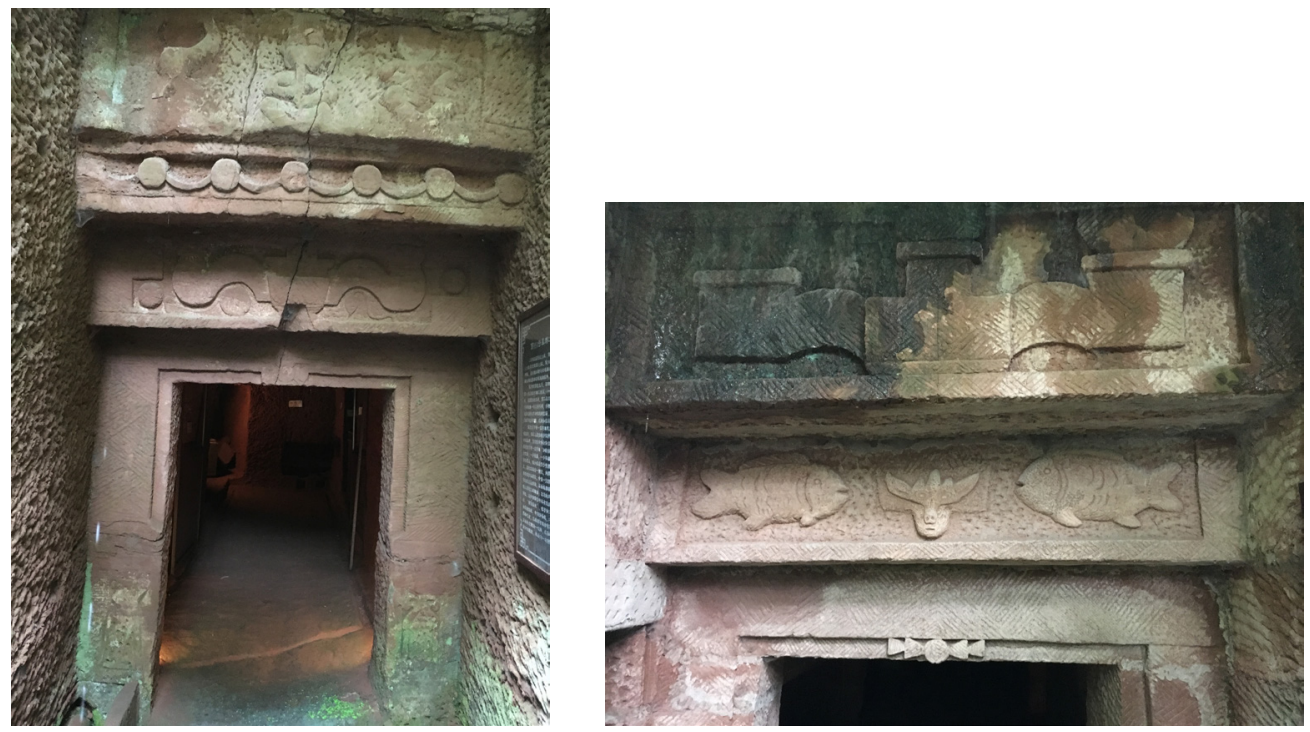

Figures 6a, 6b: Cliff tomb gates, Pengshan, Sichuan (Photos by Author). 
Carvings with auspicious connotations such as rams, fish, plants, animals, birds, que, Xiwangmu's sheng 勝 head-dress ${ }^{12}$ and images of human musicians were carved on, above or to the side of tomb gates that were fashioned to imitate wooden architectural structures. We also find depictions of intimacy, such as the remarkable carving of a seated naked couple, embracing and kissing, formerly on the lintel of the gate to tomb number 550 at Zhaizishan 寨子山, given the title "Picture of Secret Play" (“Mixi tu 秘戲圖”) by scholars (Fig. 7), and another depicting a fully clothed couple embracing and kissing, carved on a lintel at the entrance gate of a cliff tomb at Leshan (Fig. 8) (Lim 1987, 127). ${ }^{13}$ These images are significant for their explicit sexual context, and as such are considered special to the art of Sichuan. Lucy Lim (ibid.) notes how some of the most surprising finds amongst Sichuan's material culture are representations of intimacy. She further suggests that Han reliefs seem to epitomise the Sichuan artists' open and honest acceptance of life in its various aspects and the joy they took in human relationships. Scenes of such intimate nature are explained by Wu Hung to be linked to Xiwangmu, who was closely associated with fertility and the practice of the Daoist sexual arts (Wu 2000, 89). While the meaning of intimate scenes placed above entrances of cliff tombs, and also found on stone sarcophagi, remains difficult to establish with certainty, it may be suggested that they are linked to the notion of sexual union and fertility.

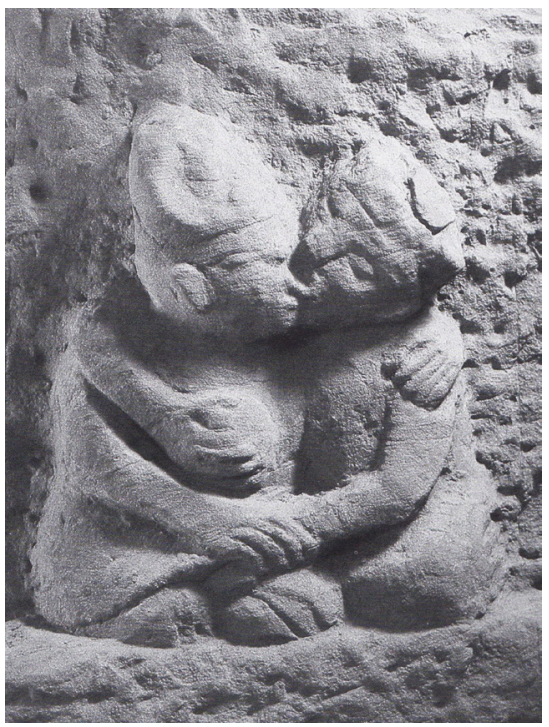

Figure 7: Cliff tomb lintel carving of "Picture of Secret Play", Pengshan, Sichuan (After Lim 1987, 131).

12 Xiwangmu 西王母 is typically depicted wearing her victory crown known as dai sheng 戴勝 or sheng 勝 over her hair. Depictions of the sheng in tomb art are known to represent Xiwangmu.

13 The relief carving of the "Picture of Secret Play" is now housed in the Beijing Palace Museum (see Lim 1987, 131). 


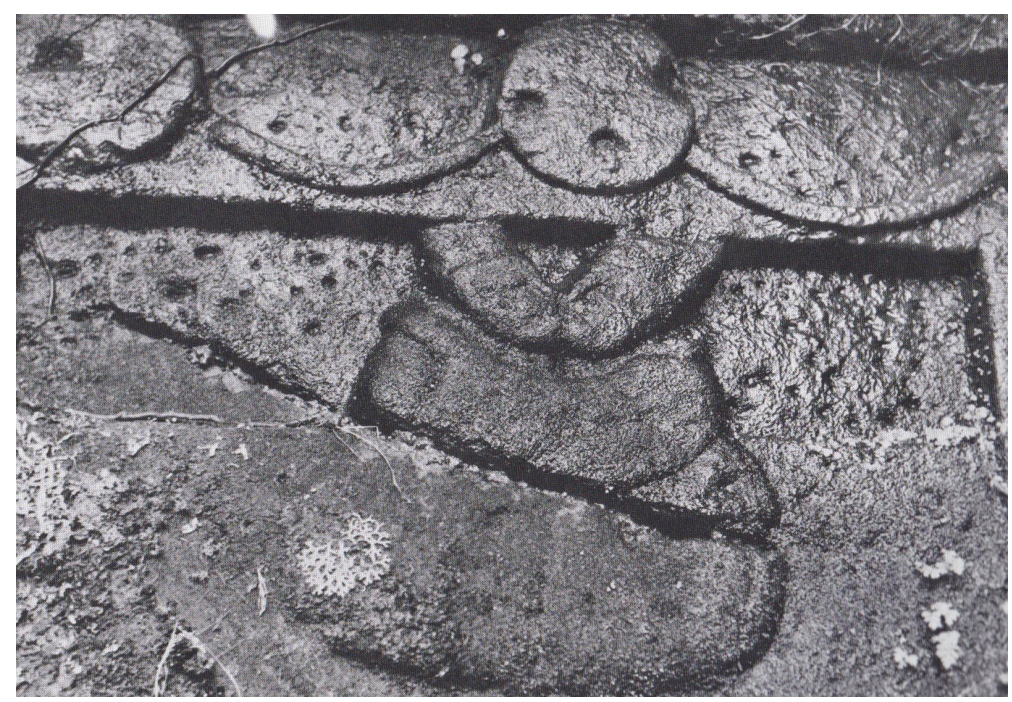

Figure 8: Cliff tomb lintel carving of couple embraced and kissing, Leshan, Sichuan (After Lim 1987, 130).

\section{Decorative Themes Found on Stone Sarcophagi}

In contrast to the lack of decoration of the walls, the inclusion of rich imagery on stone sarcophagi and the hundreds of burial objects placed in the tombs suggest that there was a continued desire to furnish tombs, although perhaps in a modified manner. The typical layout and iconography of decorative themes found on stone sarcophagi can give us an insight into the thinking about the transition in death to the afterlife at the time they were made. Pictorial carvings on stone sarcophagi were placed on the external faces and on the cover, and never in the interior. Artisans used a number of carving techniques, which included varying levels of low, high and circular reliefs on the flat and vaulted surfaces. Low relief carving incorporated delicate sunken lines for details such as facial expressions, clothing and architectural components. Outlines of the main motifs were accentuated with deeper lines in high relief which give an effect of three-dimensionality, as well as spaciousness and lightness to the design. The background was usually left plain or was densely carved with diagonal lines in high relief, similar to the effect and finish seen on the walls of cliff tombs. The prominent lines on the sarcophagi created a distinct background setting within the framework that give weight to the main pictorial theme. The arrangement of the decoration on the sarcophagi generally adheres to the following rules: one end of the coffin typically carries images that represent the entrance into the other realm with the picture of the que, the symbol of the gateway (Figs. 9a, 9b, 9c). If one end was the entrance then we may assume that the other end of the sarcophagus portrays the other realm, the abode of Fuxi 
伏羲 and Nüwa 女媧, who feature prominently together with propitious symbols and animals (Figs. 10a, 10b, 10c). ${ }^{14}$
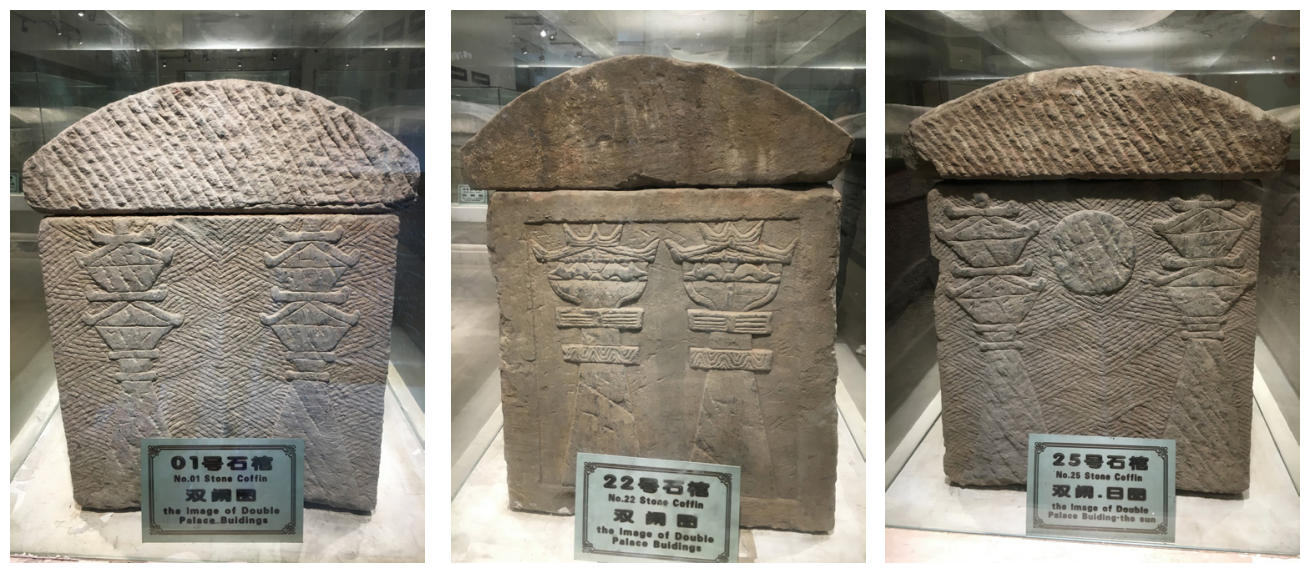

Figures 9a, 9b, 9c: Stone sarcophagi decorated with que, Hejiang and Lushan counties, Sichuan (Photos by Author).
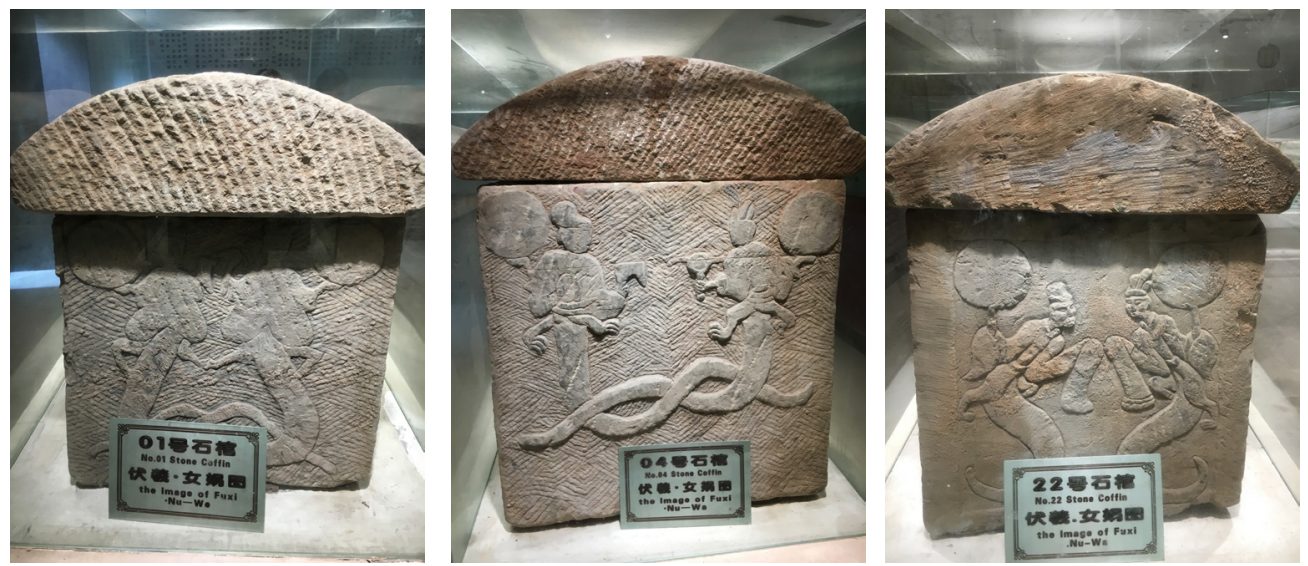

Figures 10a, 10b, 10c: Stone sarcophagi decorated with Fuxi and Nüwa, Hejiang and Lushan counties, Sichuan (Photos by Author).

Decoration on the sides of the coffin, sometimes divided into different levels and bearing a more complex pictorial programme, shows what appears to be the beginning of the deceased's journey in the lower section, and the continuation

14 See Tseng (2011, 285-90) for a detailed explanation on the representation of Fuxi and Nüxa in Han material culture. See also Powers $(1991,113-17)$ on the stylistic development, and the classical versus the analytical approach to depictions of Fuxi and Nüwa in Sichuan and North China. 
of that journey, but now perhaps in the other realm, on the upper division (Huo 2008,303 ). The pictorial iconography of the coffin appears to have been independent of its surroundings, unlike the complex pictorial programmes placed across the walls of chamber tombs, where different images were connected across the tomb space. Images found on stone sarcophagi are often scenes of everyday life activity; well-known historical figures and stories; images of auspicious and mythological importance; mansions and architectural structures; and motifs and patterns of purely ornamental nature (Luo 2000, 38-43; Gao 2011, 7-14) (Figs. 11,12).

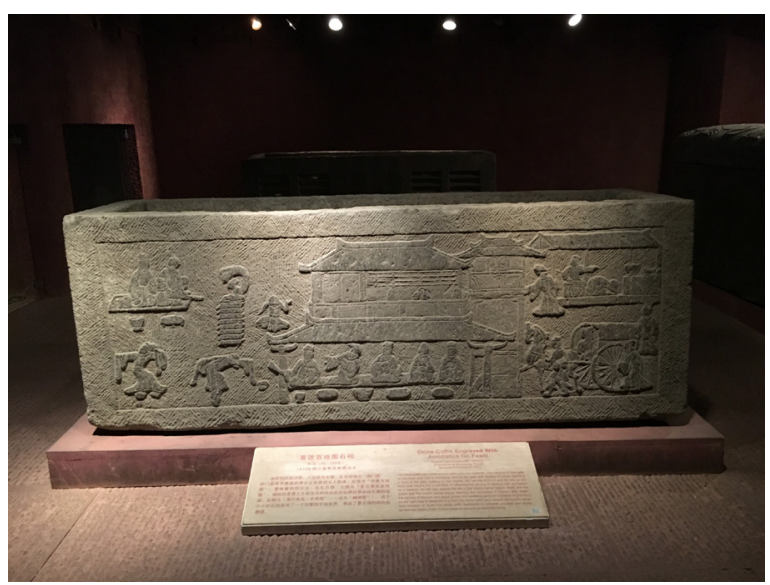

Figure 11: Stone sarcophagus decorated with a banquet scene, Pi county, Sichuan (Photo by Author).

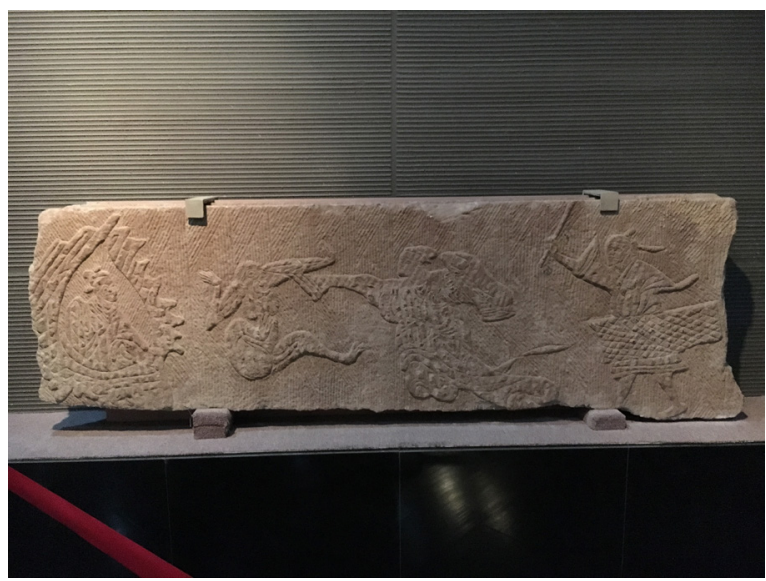

Figure 12: Stone sarcophagus decorated with the mythological tale of "Playing with Monkeys," Xinjin county, Sichuan (Photo by Author). 
One of the most important deities associated with the world of the immortals, and as such most frequently depicted on stone sarcophagi, is Xiwangmu. Depictions of her are abundant, and even when she does not appear as a carved image, she is often represented by her attribute, the sheng (Figs. 13, 14). In the Han mind, Xiwangmu dwelt in heaven, dominated other spirits, controlled access to immortality and promised ecstatic flight through space (Cahill 1993, 31). On depictions of Xiwangmu in cliff tombs David Yu notes the "cave" being significant to the theme of journey and passage. The Chinese word for caves is "dong 洞” which conveys the meaning of “tong 通” to pass through or to connect. Mountains have passes and cave-like recesses which one journeys through to reach the land of the immortals and the habitat of Xiwangmu (Yu 1986, 15). ${ }^{15}$ The significance of Xiwangmu is also related to the origins of cliff tomb burials and their connection with the local Daoist movement of the "Way of the Five Pecks of Rice," or the Wudoumi Dao 五斗米道 (Wu 2000). Depictions of large mansions also feature prominently on stone sarcophagi, such as the example from a cliff tomb at Zhangjiakou 張家口, which shows a single architectural structure, with a slightly ajar front-entrance and two figures standing on the side (Fig. 15). We can also find carvings of buildings on stilts which appear to represent the southwest's distinct local architecture (Fig. 16).

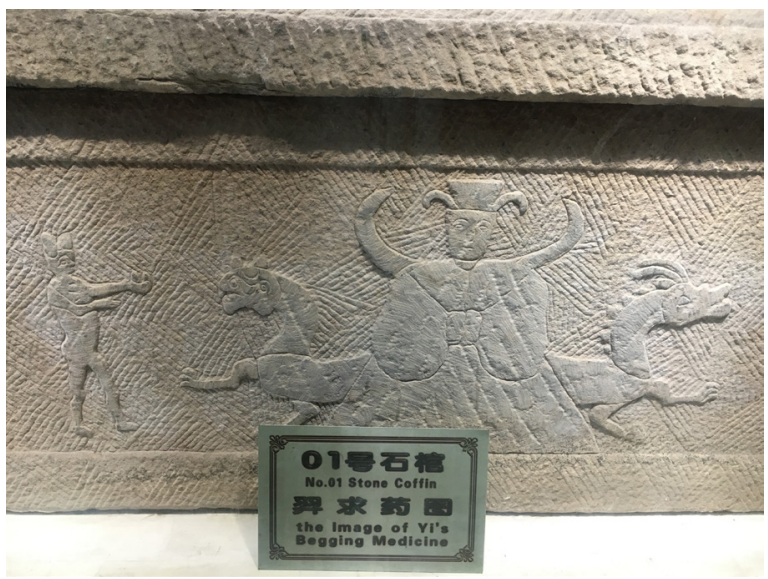

Figure 13: Stone sarcophagus decorated with Xiwangmu, Hejiang, Sichuan (Photo by Author).

15 See Jiyun 集韻 (Assembled Rhymes) (Ding 1927-1935, 7.2; “Qu sheng. Song yun” 去聲 . 送韻) where tong 洞 is explained as a variant for tong 通, meaning to penetrate or pass through. 


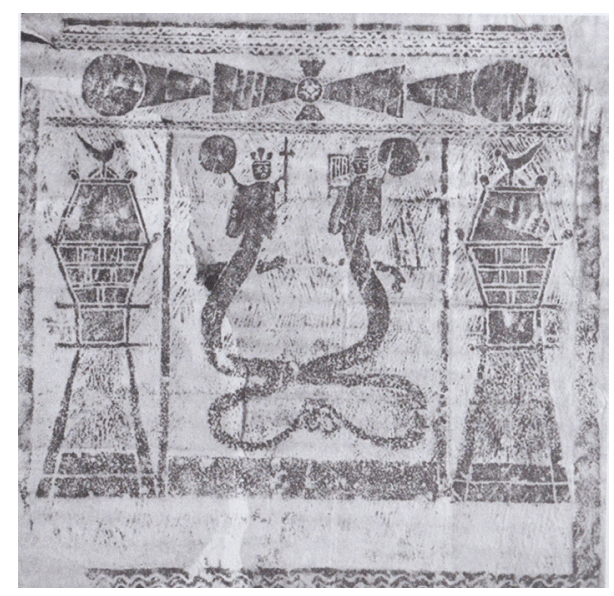

Figure 14: Rubbing of stone sarcophagus decorated with Xiwangmu's sheng, Luzhou, Sichuan (After Gao 2011, 332).

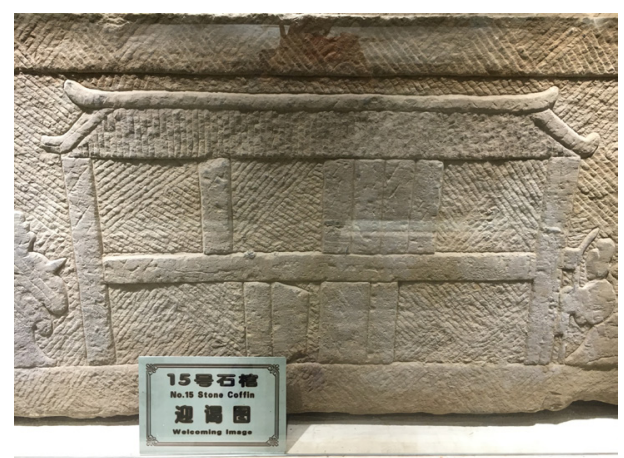

Figure 15: Stone sarcophagus decorated with a large mansion and figures, Zhangjiakou, Hejiang, Sichuan (Photo by Author).

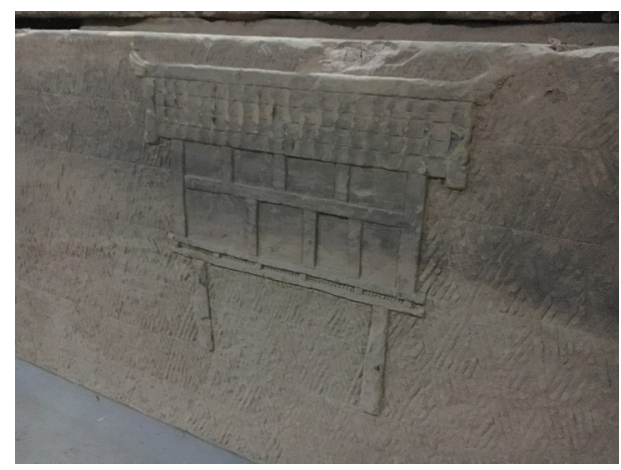

Figure 16: Stone sarcophagus decorated with a single building on stilts, Luzhou, Sichuan (Photo by Author). 
The question of why buildings were carved on sarcophagi when the tomb itself, with its architectural structures, already represented a home, as believed by scholars, needs to be addressed. The images of buildings may have served to highlight the function of the sarcophagus itself as the new dwelling of the deceased in his or her afterlife, rather than the tomb, as suggested by some scholars (Wu 2010; Rawson 1999; Nylan 2006). Bearing this in mind, the que positioned at the head of the coffin symbolises the entrance upon death into another place of being, perhaps the heavenly domain. Furthermore, if the coffin, with its mansion, represented the deceased's transition to and dwelling in the other world, then the tomb, which belonged to the family or lineage, with its homelike features, may have functioned as a communal space that provided everyone with a secure arena or shelter, but was not the designated abode of any specific person in the family. The buildings on the sarcophagi are typically depicted as large mansions, appearing to represent a wealthy and comfortable life. This may be associated with the region's prosperity at the time or perhaps with the wish, on the part of the family, for a comfortable existence for the deceased in his or her afterlife.

In summary, depictions of local buildings as well as mythological figures, such as Xiwangmu, Fuxi and Nüwa, provided representations appropriate to people's final resting place and transition to the afterlife. Both Michael Loewe and $\mathrm{Mu}-\mathrm{chou} P$ Poo mention how early writings devoted little attention and speculation to describing life after death. Comparing Confucian, Mohist and Daoist texts, Poo notes that a common feature that emerges is a reticence to debate post-mortem existence and whether or not there is life after death, or what that afterlife may be (Loewe 1994, 115; Poo 1990, 38). In her study of mourning in the Eastern Han, Miranda Brown also suggests that people perhaps focused on the experience of loss because the life to come was not celebrated at the time. Eulogists whose writings are found on stelae questioned outright whether personal survival after death was possible, though they did believe that the dead lived on in communal memory as moral exemplars (Brown 2007, 17). Another view suggests that perhaps death was not seen as final, and a post-death journey of the soul was indeed a possibility. The goal of ascending to the heavens could be realised with the aid of mountains, animal vehicles, specific deities and auspicious surroundings (Erickson 1994,18). Whatever death may have meant for people at the time, it is clear that certain ideas, left unarticulated in writing because of their inherent elusiveness, were nevertheless imaginatively expressed and alluded to in pictorial form on the sarcophagi of the period.

\section{Possible Reasons for the Shift in Burial Practice and Tomb Decoration}

Scholars have noted the lack of decoration on cliff tomb walls in contrast to the intricate carvings found on stone sarcophagi within the tombs. Luo Erhu suggests 
that because sarcophagi already relayed images, there was no need to repeat these on the walls. He further proposes that decorated stone sarcophagi, as opposed to those made of other materials, may have been reserved for the head of the family, or the most eminent member buried in the tomb (Luo 2002, 49). His conclusion is based on the examination of the fourteen sarcophagi found in a multi-chamber cliff tomb at Tianhuishan 天回山 near Chengdu. Amongst the coffins, eleven are made of earthenware, one of brick and two of stone. Of the two stone coffins, one was built on a platform chiselled out of the wall and left undecorated, while the other is finely carved on one side with a picture of a large mansion and with figures and animals on the other. The front of the coffin is carved with the que motif, while the head bears the outlines of an unfinished building suggesting that the decoration may not have been completed in time for the burial (Luo 2002). It may also suggest that that the period between coffining and the internment ceremony may have become shorter than originally thought. ${ }^{16}$ The Tianhuishan stone sarcophagus' lid is made in the shape of a gabled roof, consistent with the notion that the coffin represents a home or dwelling. ${ }^{17}$ Inside the coffin a gilded iron book knife was found with an inscription attributing its manufacture to the Guanghan workshop (Guanghan gongguan 廣漢 工官). This workshop was responsible for the production of luxury goods of tribute for the Eastern Han court. It is an important find that confirms the high status and eminence of the deceased placed in the coffin, and supports Luo's suggestion that the deceased was possibly the head of an extensive clan (ibid.). The differences found between decorated and non-decorated coffins, as evident from the Tianhuishan cliff tomb burial, suggests that there was a hierarchy established within the tomb and those of importance were buried in distinctly decorated and more lavish coffins.

Erickson has also noted the general scarcity of any decoration found in cliff tombs compared to those in chamber tombs. She suggests that this is because the images placed in chamber tombs were sculpted or moulded on panels outside the tomb and then installed. By contrast, images in cliff tombs were carved directly into the living rock (Erickson 2003, 434). While this explanation may present a practical reason for the scarcity of tomb wall decoration, it does not explain the artistic or communicative objectives behind this fundamental shift.

Bearing the above mentioned studies in mind, we suggest two possible explanations for the change in the decorative practices that have been observed. The first

16 This contradicts Miranda Brown's suggestion that many members of the Han elite were in no great hurry to bury their dead, since they presumably were not eager to separate their deceased loved ones from the living. She further notes that the internment ceremony was often put off from several months to even several years (see Brown 2007,16). In the southwest, however, it appears that burial of the dead was seen as a priority, even if the decoration of the coffin was not completed.

17 During my fieldwork in Hejiang and Pengshan counties, I found that about one third of the stone sarcophagi had lids shaped after garbled roofs. 
addresses the question as to who commissioned the making of the tomb. The housing of several coffins in one tomb and its re-opening, perhaps not only once but on several occasions at different periods, suggests that tombs came to cater to the needs of the family or lineage rather than a single individual, and the building of tombs must have become a family responsibility expanding over a number of generations. If we regard the interior of the tomb as a communal "family" space, as suggested earlier, with less emphasis on the individual, the coffin may have become the main carrier of personal memorial and identity, as well as the means of the deceased's transition to and dwelling place in the afterlife. Decoration placed on the walls of chamber tombs would have related to the burial chamber as a whole and addressed a wider audience, which included the mourners gathered at the time of burial, while decoration on the sarcophagus had a more personal connotation, and as such was directly linked to the deceased. This suggestion is supported by social developments of the Eastern Han period, when we see the rise of major lineages or great families who became influential on a regional level (Lewis 2007, 121). Mark Lewis equates the emergence of these locally powerful families with the decline of the central court, and the consequent shift of authority from the capital to the regions. He notes that much of the history of the Eastern Han is, accordingly, the history of lineages and factions with regional power bases (ibid., 24). Patricia Ebrey explains that on the one hand, these lineages were established by local leaders who earned the respect of their contemporaries for gathering together a loyal following and using it to administer a locality with justice, efficiency and generosity. On the other hand, they were also recognised as being a threat to the effective control of centrally authorised officials (Ebrey 1986, 630). The use of cliff tomb complexes, which may have been employed over several generations, is consistent with the increased visibility and self-awareness of such lineages during a period of relative economic and political stability.

Another explanation for the shift in the decorative practice may be due to a wish for more moderate display in burial matters in a society that enjoyed great economic wealth and prosperity. A preference for thrift and restraint is expressed in the two commemorative stelae dedicated to Shu Commandery 蜀郡 governors, $\mathrm{Li}$ 李 and Pei 裴, dated to $133 \mathrm{CE}$ and $144 \mathrm{CE}$, respectively. According to the stelae inscriptions, the two governors encouraged society to pursue a prudent and less lavish lifestyle (Elias 2018). An ancestral stele erected for the Ba commandery 巴郡 xiaolian Liu Min, mentioned earlier, also affirms intentional moderation and restraint from display and extravagance as a style of burial, and celebrates a preference for frugality and moderation in accordance with the Liu family's traditions (ibid., 139-41). This type of motive may have been a factor in the shift towards the use of cliff tomb burials in a region which was inherently more modest in appearance, rather than the use of extensive cemetery layouts of chamber tomb burials. A drive for less lavish display may well have encouraged people to 
reassess the levels of display in their burial practices. Whether a sarcophagus was intricately or sparsely decorated, a considerable level of expertise was required in its making, which was undoubtedly time consuming and certainly more costly than the production of a wooden or earthenware coffin. Thus a seemingly more modest and understated form of burial was probably not without considerable cost. The objective may have been to avoid ostentatious display rather than reduce costs, since the overriding purpose was to perform the correct funerary procedures for the deceased.

\section{Conclusion}

Examination of the images found in cliff tombs and on stone sarcophagi reveals that decoration on the latter appears to have served as the primary visual enhancement placed in the interior of the cliff tomb, at times in combination with limited architectural structures and burial furnishings. Although carvings with auspicious connotations were placed at the exterior of tomb gates, inside the tomb walls were usually left plain or only minimally decorated. This decorative scheme represents a shift from what we see in chamber tombs from the southwest, where pictorial images were placed on the walls, either carved in stone or made of fired earth in the form of moulded brick tiles that appear to have been produced in large quantities, as we see from the many extant examples today.

The change in the decorative scheme between chamber tombs and cliff tombs suggests that there was a shift in burial custom, in the target audience of mourners and, perhaps most importantly, in the establishment of the tomb as a communal space for the family or lineage rather than the final resting place of only one deceased person. While decoration placed on the walls of chamber tombs, which in many instances extended from the entrance through the main chamber and even to the rear chambers, took the entire tomb space as its canvas, that found in cliff tombs was inherently more modest and simple. Decorative themes placed on stone sarcophagi are individual, with no two coffins ever the same, suggesting a personalised choice that was more likely to have been directly connected to the deceased. We also observed the distinctly regional nature of images carved on sarcophagi. This is in sharp contrast with the many pictorial brick tiles found in tombs, that appear to have been mass produced with the use of the same mould, thus resulting in identical images placed in different tombs. The prevalence of depictions on the sarcophagi of buildings, gateways and the image of a half-open door embody representations of a final ideal dwelling and indicate an understanding of death as a threshold to another realm. In this context, stone sarcophagi in cliff tombs may have symbolised the new heavenly residence of the departed, while the tomb as a whole functioned as a shared burial space for the family or lineage. 
Another important observation made regarding the development of cliff tomb burials is the change in the layout of the cemetery which differed significantly from that of the established chamber burial cemeteries of the Eastern Han period. The absence of public monuments leading to the tombs, such as the walls, moats, spirit path, stone markers, stelae, mounds and shrines, must have made cliff tomb internment a different undertaking from earlier traditions. We see no evidence of shrines in the immediate vicinity nor remains of any above ground structures that may have been linked to the tombs. This reflects a shift in the function of cemeteries from being social or public arenas towards private spaces that focussed primarily on the deceased and their family members. Cliff tomb burials came to represent an important adaptation in how society in the southwest became more focused on the family or lineage in its greater surroundings. The burial of not only several family members but even different generations in one tomb or tomb complex is another new development in Eastern Han funerary practice. The layout and construction of cliff tombs confirm this trend, and affirm the rise and power of the lineage, especially in the southwest.

Cliff tomb burials developed during a period in the southwest's history when it experienced relative social and political stability and great economic prosperity. Early texts describe the southwest as well irrigated and containing rich soil that produced abundant food, making it one of the wealthiest regions in the empire at the time. Its established waterways and roads, as we read in the Shiji 史記, made it a centre of trade between the West and Central Plains (Sima 1959, 116.2994). Economic wealth and general social stability helped create a conducive environment for the development of cliff tomb construction and its prolific use in this period. An analysis of the principle locations of cliff tomb developments in Sichuan shows that they served the population centred in its largest cities located within a short travelling distance, such as the Shu commandery capital of Chengdu and the Ba commandery capital of Jiangzhou 江州 (present-day Chongqing city), on the banks of the Yangtze.

We have also seen evidence of a wish for moderation and frugality in a society that was criticised by its own people for unnecessary extravagance. Frugality and restraint were reflected in a burial custom that was less showy and more family orientated and personal, yet had all the ritual elements required in a proper funeral. In its more modest presentation cliff tomb burials may have been a reaction to the increasingly lavish funerary customs that came to prevail in the wider empire, especially in the Central Plains. Furthermore, its sudden rise in the Eastern Han period and decline by the 3rd century $\mathrm{CE}$ suggest that it was a trend that answered a particular call at a specific period.

Due to the scarcity of supporting material many questions regarding the origins and rise of cliff tomb burial practice and the use of decorated stone sarcophagi 
remain difficult to answer. For example, the identity of the majority of those buried in cliff tombs is unknown, nor do we know how the funeral protocol for cliff tomb burial was conducted. Limited space for public gatherings at the cliff tomb cemetery does not mean that mourning and rituals were not conducted, but they may have been shifted elsewhere. However, cliff tombs and decorated stone sarcophagi were clearly a distinctive feature of the southwest in early Imperial China.

\section{References}

Asselin, Mark Laurent. 2010. A Significant Season: Cai Yong (ca. 133-192) and His Contemporaies. New Haven, Conn.: American Oriental Society.

Ban, Gu 班固. 1962. Hanshu 漢書 (History of the Western Han). Beijing: Zhonghua shuju.

Brashier, Kenneth. 2014. Public Memory in Early China. Cambridge and London: Harvard University Press.

Brown, Miranda. 2007. The Politics of Mourning in Early China. Albany: State University of New York Press.

Cheng, Te-k'un. 1957. Archaeological Studies in Szechwan. Cambridge: Cambridge University Press.

Davis, Timothy M. 2015. Entombed Epigraphy and Commemorative Culture in Early Medieval China. A History of Early Muzhiming. Leiden and Boston: Brill.

Ding, Du 丁度 et al., ed. 1927-1935. “Jiyun 集韻 (Assembled Rhymes).” In Sibu jiyao jingbu 四部集要經部 (Four Divisions of Collectanea of the Classics). Shanghai: Zhonghua shuju.

Ebrey, Patricia. 1986. "The Economic and Social History of Later Han." In The Cambridge History of China, Volume 1, The Ch'in and Han Empires, 221 BC$A D$ 220, edited by D. Twitchett and M. Loewe, 608-48. Cambridge: Cambridge University Press.

Elias, Hajni. 2018. "The Southwest: A Study of Regional Identity in Material Culture and Textual Sources during the Eastern Han Dynasty (25-220 CE).” $\mathrm{PhD}$ diss., University of Cambridge.

Erickson, Susan N. 1994. "Money Trees of the Eastern Han Dynasty." Bulletin of the Museum of Far Eastern Antiquities 66: 5-115.

—. 2003. "Eastern Han Dynasty CliffTombs of Santai Xian, Sichuan Province." Journal of East Asian Archaeology 5: 401-69.

Fan, Ye 范曄, comp. 1965. Hou Hanshu 後漢書 (Book of the Later Han). Beijing: Zhonghua shuju.

Gao, Wen 高文. 1990. Sichuan lidai beike 四川歷代碑刻 (Historical Stelae Carvings from Sichuan). Chengdu: Sichuan daxue chubanshe. 
—.2002. Zhongguo Ba Shu Handai huaxiangzhuan daquan 中國巴蜀漢代畫像磚 大全 (Complete Collection of Han Dynasty Pictorial Brick Tiles from Ba and Shu China). Hong Kong and Macao: GangOu International Publishing Company.

—. 2011. Zhongguo huaxiang shiguan quanji 中國畫像石棺全集 (Complete Collection of Pictorial Stone Sarcophagi from China). Taiyuan: Sanjin chubanshe.

$\mathrm{He}$, Yun'ao 賀雲朝. 1993. Fojiao chuchuan nanfang zhi lu wenwu tulu 佛教初傳南 方之路文物圖錄 (The Route of the Earliest Buddhist Transmission to the South: A Pictorial Record of the Cultural Relics). Beijing: Wenwu chubanshe.

He, Zhiguo 何志國. 2006. Han Wei yaoqianshu chubu yanjiu 漢魏搖錢樹初步研 究 (Initial Research on Money Trees from the Han and Wei Dynasties). Beijing: Kexue chubanshe.

Huo, Wei 霍巍. 2007. “Zhongguo xinan diqu qianshu fuoxiang de kaogu faxian yu kaocha 中國西南地區錢樹佛像的考古發現與考察 (Archaeological Discovery and Examination of Buddha Figures Found on Money Trees from China's Southwest Region).” Kaogu 考古 3: 70-81.

- 2008. "Center and Periphery: The Expansion and Metamorphosis of Han Culture-A Case Study of Stone Carvings in No. 1 Mahao Cave Tomb, Leshan, Sichuan Province, China." Frontiers of History in China 3 (2):293-322.

Lewis, Mark. 2007. The Early Chinese Empires. Qin and Han. Cambridge, Mass. and London: The Belknap Press of Harvard University Press.

Li, Daoyuan 麗道元, comp. 1989. Shuijing zhushu 水經注疏 (Commentaries to the River Classic). Edited by Yang Shoujing 楊守敬 and Xiong Huizhen 熊會貞. Nanjing: Jiangsu guji chubanshe.

Lim, Lucy, ed. 1987. Stories from China's Past: Han Dynasty Pictorial Tomb Reliefs and Archaeological Objects from Sichuan Province, People's Republic of China. San Francisco: Chinese Culture Center.

Liu, Xixiang 劉習祥. 2007. “Xinxiang Fenghuangshan Zhanguo liang Han mudi yanjiu 新鄉鳳凰山戰國兩漢墓地研究 (Research on Warring States and Western and Eastern Han Dynasty Cemeteries at Mount Fenghuang in Xinxiang).” Zhongyuan wenwu 中原文物 6: 46-49.

Loewe, Michael. 1994. Chinese Ideas of Life and Death. Taipei: SMC Publishing Inc.

—. 2011. Dong Zhongshu, a 'Confucian' Heritage and the Chunqiu Fanlu. Leiden and Boston: Brill.

Luo, Erhu 羅二虎. 2000. “Handai huaxiang shiguan yanjiu 漢代畫像石棺研究 (Research on Han Dynasty Pictorial Sarcophagi).” Kaogu xuebao 考古学报 1: 31-61.

—. 2002. Handai huaxiang shiguan 漢代畫像石棺 (Han Dynasty Pictorial Stone Sarcophagi). Chengdu: Bashu shushe.

—. 2005. “Zhongguo xinan zaoqi foxiang yanjiu 中國西南早期佛像研究 (Research on Early Buddhism in the Southwest of China)." Kaogu 考古 6: 66-73. 
Mengoni, Luisa Elena. 2004. "Identity, Culture and Social Change in Ancient Sichuan, China." Archaeology International 8: 52-55.

—. 2010. "Identity Formation in a Border Area: The Cemeteries of Baoxing, Western Sichuan (Third Century BCE-Second Century CE).” Journal of Social Archaeology 10: 198-229.

Nylan, Michael. 2006. "Ordinary Mysteries: Interpreting the Archaeological Record of Han Sichuan." Journal of East Asian Archaeology 5: 375-400.

Nylan, Michael, and Michael Loewe, eds. 2010. China's Early Empires. Cambridge: Cambridge University Press.

Nylan, Michael, and Griet Vankeerberghen, eds. 2015. Chang'an 26 BCE. An Augustan Age in China. Washington D.C.: University of Washington Press.

Orioli, Marcello. 1994. "Pastoralism and Nomadism in South-West China: A Brief Survey of the Archaeological Evidence." In The Archaeology of the Steppes, Methods and Strategies, edited by Bruno Getino, 87-108. Naples: Instituto Universitario Orientale.

Poo, Mu-chou. 1990. "Ideas Concerning Death and Burial in Pre-Han and Han China." Asia Major 3: 25-62.

Powers, Martin. 1991. Art and Political Expression in Early China. New Haven: Yale University Press.

Rawson, Jessica. 1999. "The Eternal Palaces of the Western Han: A New View of the Universe." Artibus Asiae 59: 1-35.

Sichuan sheng wenwu kaogu yanjiuyuan 四川省文物考古研究院. 2014. “Sichuan sheng wenwu kaogu yanjiuyuan kaogu 60 nian 四川省文物考古研究院考古 60年 (60 Years of Archaeology by the Sichuan Province Cultural and Archeological Institute).” Sichuan wenwu 四川文物 1: 80-96.

Sima, Qian 司馬遷. 1959. Shiji 史記 (The Grand Scribe's Records). Beijing: Zhonghua shuju.

Tang, Changshou 唐長壽. 1993. Leshan yamu yu Pengshan yamu 樂山崖墓與彭 山崖墓 (Cliff Tombs at Leshan and Pengshan). Chengdu: Dianzi keji daxue chubanshe.

Sage, Stephen S. 1992. Ancient Sichuan and the Unification of China. Albany: SUNY Press.

Su, Bai 宿白. 2004. “Sichuan qianshu he Changjiang zhong xiayou bufen qiwu shang de foxiang 四川錢樹和長江中下游部分器物上的佛像 (Buddha Figures Found on Utensils from the Downstream of the Yangtze River and Money Trees from Sichuan)." Wenwu 文物 10: 61-71.

Tseng, Lillian. 2011. Picturing Heaven in Early China. Cambridge: Harvard University Press.

Wade, Geoff. 2009. “The Polity of Yelang (夜郎) and the Origins of the Name 'China'." Sino-Platonic Papers 188: 1-26. 
Wang, Chong 王充, 1990. Lunheng jiaoshi 論衡校釋 (Critical Explanation of the Balanced Discussions). Edited by Huang Hui 黃暉 and commentary by Liu Pansui 劉盼遂. Beijing: Zhonghua shuju.

Wen, You 聞宥. 1955. Sichuan Handai huaxiang xuanji 四川漢代畫像選集 (Complete Collection of Han Dynasty Portraits from Sichuan). Beijing: Wenwu chubanshe.

Wu, Hung. 1986. "Buddhist Elements in Early Chinese Art (2nd and 3rd Century AD).” Artibus Asiae 47 (3): 263-352.

—. 1987. "The Earliest Pictorial Representations of Ape Tales." T'oung Pao 73: 86-112.

- 1995. Monumentality in Early Chinese Art and Architecture. Stanford: Stanford University Press.

—. 2000. "Mapping Early Taoist Art: The Visual Culture of Wudoumi Dao." In Taoism and the Arts of China, edited by Steven Little and Shawn Eichman, 77-93. Chicago: The Arts Institute of Chicago.

- 2010. The Art of the Yellow Springs. London: Reaktion Press.

Wu, Zhuo 吴焯. 1992. "Sichuan zaoqi fojiao yiwu qiji niandai yu chuanbo tujing de kaocha 四川早期佛教遺物其及年代與傳播途徑的考察 (Research on the Date and Transmission of Early Buddhist Relics from Sichuan).” Wenwu 文物 11: 40-50, 67 .

Xie, Ling 謝凌. 2000. “Sichuan diqu cun zhuyao mingke ji qi yishu tese 四川地 區存主要銘刻及其藝術特色 (Important Inscriptions from the Sichuan Region and Their Artistic Features).” Sichuan wenwu 四川文物 4: 18-25.

Xu, Xueshu 余學書. 1995. “Minjiang shangyou xinshiqi shidai wenhua de chubu yanjiu 岷江上游新石器時代文化的初步研究 (Preliminary Research into the Culture of the Upper Streams of the Min River During the Neolithic Period).” Kaogu 考古 5: 415-26.

Xuan, Chen. 2015. Eastern Han (AD 25-220) Tombs in Sichuan. Oxford: Archaeopress.

Yu, David. 1986. "The Creation Myth of Chaos in the Daoist Canon." Journal of Oriental Studies 24 (1): 1-20.

Yu, Haoliang 于豪亮. 1955. “Ji Chengdu Yangzishan yi hao mu 記成都揚子山一 號墓 (Recording Number One Tomb from Yangzishan in Chengdu).” Wenwu 文物 9: 70-81.

Yu, Weichao 俞偉超. 1980. “Dong Han fojiao tuxiang kao 東漢佛教圖像考 (Examination of Eastern Han Dynasty Buddhist Images).” Wenwu 文物 5: $68-77$. 